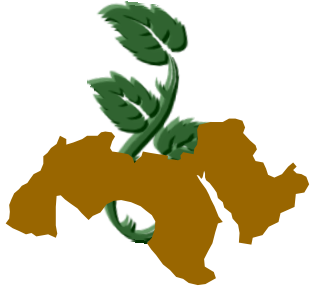

\title{
RESPONSE OF RICE AND ASSOCIATED WEEDS TO BIOREGULATOR (BIO HORM) SPRAY AND WEED MANAGEMENT IN SALINITY SOIL
}

\author{
Tagour $^{1}$, R.M.H.; G.M. Abd El-Hamed ${ }^{1}$ and I.M. El-Metwally ${ }^{2}$ \\ 1- Weed Research Laboratory, Agricultural Research Center, Giza, Egypt \\ 2- Mubarak City For Scientific Research, Arid Lands Cultivation and Development Research \\ Institute, Borg El-Arab, Egypt
}

Keywords: Weed management, Rice, Hand weeding and Salinity soil

\section{ABSTRACT}

Two field experiments were conducted during the two successive seasons of 2007 and 2008 at the Agricultural Experimental Station of Agricultural Research Center, at EL-Serw, Damietta Governorate Egypt, to study the effect of the bio horm and weed control treatments (Bentazon, Pyrazosoulfuron, Fenoxaprop, Penoxsulam, Bentazon + Fenoxaprop, Bentazon + Penoxsulam, Pyrazosoulfuron + Fenoxaprop, Pyrazosoulfuron + Penoxsulam, twice hand weeding and un- weeded check ) on growth, yield, its components and NPK percentage in grains of direct seeded rice as well as associated weeds in salinity soil. Results illustrated that application of bio horm increased fresh and dry weight of total weeds. Spraying bio horm after 50 days from sowing (DFS) markedly increased rice growth characters (plant height, number of productive tillers, fresh and dry weight of rice plants), yield and yield components (panicle length, number of panicles $/ \mathrm{m}^{2}$, weight of 1000 grain, grain and straw yield) and $\mathrm{N}, \mathrm{P}$ and $\mathrm{K} \%$ of grain rice, as compared with untreated treatment. All weed control treatments caused significant reduction on number, fresh and dry weight of total weeds $/ \mathrm{m}^{2}$ after 60 DFS in both seasons. Pyrazosoulfuron treatment gave the highest decrease in total number of weeds followed by Pyrazosoulfuron + Penoxsulam and Pyrazosoulfuron + Fenoxaprop treatments. Pyrazosoulfuron + Fenoxaprop treatment gave the highest decrease in total fresh weight of weeds followed by Bentazon + Penoxsulam, Pyrazosoulfuron and Pyrazosoulfuron + Penoxsulam, respectively in the first season. While, in the second sea- son Pyrazosoulfuron treatment gave the lowest values of total fresh weight of weeds. Meanwhile, Bentazon + Penoxsulam was more effective than other treatments in reducing the dry weight of total weeds in both seasons. All herbicidal treatments and hand weeding increased significantly growth, yield, yield components and chemical composition of grain rice. Bentazon + Penoxsulam was superior treatment for increasing number of productive tillers, number of panicles $/ \mathrm{m}^{2}, 1000$ - grain weight and grain and straw yield as well as NPK percentage of rice grains in both seasons. While, the same treatment Bentazon + Penoxsulam recorded the highest values of plant height, fresh and dry weight of whole plant and panical length in the first season. While, Pyrazosoulfuron + Penoxsulam gave the highest increment in plant height, fresh and dry weight of whole plant and straw yield in the second season. The interaction between bio horm and weed management treatments had significant effect on total fresh and dry weight of weeds, number of productive tillers and 1000 grain weight. Pyrazosoulfuron produced the maximum values of number of productive tillers when bio horm was used in the second season, while, application of Bentazon + Penoxsulam gave the highest values of 1000 grain weight when bio horm was used in the second season. It could be concluded that using the bioregulator (bio horm) resulted in increment of growth and productivity of rice crop under salinity soils. Using the combinations of herbicides caused more reduction of weeds and increased rice grain yield.

\section{INTRODUCTION}

Rice is the second most important cereal crops in the world. It constitutes food for over half (54\%) 
of the world's population. In Egypt, rice is the second staple food after wheat and is very important for local consumption, as well as for export. In Egypt, rice annually grown in more than one million feddan, mostly in the Northern part of the Nile Delta. The cultivation area in 2006 season was 1.59 million feddan, produced about 6 million tons of paddy rice with an average yield of about $10.1 \mathrm{t} / \mathrm{ha}$, which is considered one of the highest average yield in the world

Slinity problem is obviously occurring in $70 \%$ of North of Nile Delta and electrical conductivity may exceed $8 \mathrm{ds} / \mathrm{m}$ in saturated soils. Rice is moderately susceptible to salinity. Plant growth regulators and antioxidant (GA3, Kinetin, Ascorbic acid, Salicylic acid, Citric acid, Amino acid and other materials) are widely applied for crop improvement. These regulators protect plant from various stress e.g. salinity and drought (Li et al 1998). Applying growth regulators, especially cytokinin, modify morphological and physiological characteristic of plant and may also induce better adaptation of plant to environment which improving the growth and yield. Kinetin is one of the cytokinins known to improve the growth, yield and chemical constituents of many crops (Salama and Awadalla, 1987). Amin, (2003) reported that growth characters, yield and yield components as well as chemical constituents significantly responded to foliar application with $40 \mathrm{mg} / \mathrm{L}$ kinetin. Abd El-Fattah, (2008) found that the kinetin increased growth, yield and yield components as well as chemical compositions in grains rice under saline condition.

Ascorbic acid and citric acid are a common antioxidant component in the apoplast and had effects on plant growth and many physiological processes. L-Ascorbic acid serves as a co-factor for many enzymes (Arrioni and DeTullio, 2002) and it contributes to the detoxification of reactive oxygen species (Conklin and Barth, 2004). Foliar spray of ascorbic acid and citric acid have a positive effect on plant growth and yield of many crops (Mourad, 2006 and Al-Kahal et al 2008).

Weed control is one of the essential cultural practices for raising rice yield and improving its quality. Using chemical weed management in intensively grown crops (e.g. rice) is easier and more economical than manual or mechanical ones, especially after labors scarce and pay rise. But under the warnings manipulating herbicides recently, the supply of their authorized components became extremely restricted. As well known rice is a vital and strategic food crops. Most available herbicides used in rice are assigned for controlling particular weeds, unlike little (e.g. Benthiocarb) that controls broad spectrum of weeds. However, one or more of these weed species may appear resistant of herbicides. So, it's essential to use mixtures (combinations) of herbicides for broadening the spectrum of weed control and for reducing the risk of evolution weed resistance against herbicides. The benefits of using herbicide mixtures include also saving time, control efforts and costs.

Many researchers have been reported that herbicides application attended to provide a great weed control and maximum yield of rice (Larelle et al 2003 and Cavanna et al 2004) by using Penoxsulam, (Govindra et al 2003); Fenoxaprop - p ethyl (Saini, 2003 and Mondal et al 2005) and by using pyrazosoulfuron. El-Desoki, (2002) found that two hand weeding at 20 and 40 days after transplanting was very effective in controlling rice weed growth and increasing the yield. Zhang et al (2005) stated that the combination of Fenoxaprop with Bentazon controlled effectively both broad and narrow leaved weeds and increased rice grain yield. Similarly, Pyrazosulfuron with molinate controlled broad and narrow leaved weeds in rice and increased rice grain yield compared to single application (Moorthy, 2002).

Therefore the present study aimed to investigate: (1) the role of the bio regulator (Bio horm) in improving the growth and yield of rice and its effects on the associated weeds under saline conditions. and (2) the efficacy of some herbicides used alone and combined in sequence on growth, yield, yield components and some chemical compositions of rice grains as well as associated weeds.

\section{MATERIALS AND METHODS}

Two field experiments were conducted during the two successive seasons of 2007 and 2008 at the Agricultural Experimental Station of Agricultural Research Center, at EL-Serw, Damietta Governorate, Egypt, to study the effect of biohormone and weed control treatments on growth, yield and its components and NPK percentage of grains on direct seeded rice as well as associated weeds in salinity soil. The chemical and physical analysis of the used soil during the two growing seasons are illustrated in Table (1). The soil analysis done according to Chapman and Pratt (1978). 
Table 1. The chemical and physical analysis of used soil during the two growing seasons

\begin{tabular}{|c|c|c|c|c|c|c|c|c|c|c|c|}
\hline \multicolumn{5}{|c|}{ Particle Size distribution } & \multirow{2}{*}{$\begin{array}{c}\text { PH } \\
\text { Of soil } \\
\text { Susp } \\
1: 25 \\
\end{array}$} & \multirow[b]{2}{*}{$\begin{array}{c}\text { E.C } \\
\text { ds } / m \\
\text { At } 25 c^{\circ}\end{array}$} & \multirow{2}{*}{ OM } & \multirow[b]{2}{*}{$\begin{array}{c}\text { Total } \\
\text { N } \\
\%\end{array}$} & \multirow{2}{*}{$\begin{array}{c}\text { Available } \\
\text { N } \\
\text { ppm }\end{array}$} & \multirow{2}{*}{$\begin{array}{c}\text { Available } \\
\text { P } \\
\text { ppm }\end{array}$} & \multirow[b]{2}{*}{$\begin{array}{c}\text { Available } \\
\qquad \begin{array}{c}\mathrm{K} \\
\mathrm{ppm}\end{array}\end{array}$} \\
\hline $\begin{array}{c}\text { Coarse } \\
\text { sand } \\
\% \\
\end{array}$ & $\begin{array}{c}\text { Fine } \\
\text { sand } \\
\% \\
\end{array}$ & $\begin{array}{l}\text { Silt } \\
\%\end{array}$ & $\begin{array}{c}\text { Clay } \\
\%\end{array}$ & Texture & & & & & & & \\
\hline 0.24 & 17.65 & 17.52 & 64.59 & Clayey & 8.7 & 3.6 & 1.20 & 0.038 & 32 & 8.30 & 520 \\
\hline
\end{tabular}

A split plot design with four replicates was used where the main plots were arranged to study the effect of with and without Bio horm treatments. The plot area was $16 \mathrm{~m}^{2}(4 \mathrm{~m} \times 4 \mathrm{~m})$ in both seasons. Bio horm consists of: Kinetin, Citric and Ascorbic acid as well as Fulvic Cids with: L Free Amino Acids $20 \%$, Molybdenum (MO) $4 \%$ and $\mathrm{CO} 0.005 \%$. Bio horm applied at the rate of $50 \mathrm{~mL}$ with $200 \mathrm{~L}$ water/fed after 50 DFS. The sub- plots included ten weed control treatments as follows:

1- Bentazon AS 48\% (Basagran) was applied at rate of $1.5 \mathrm{~L} /$ fed after 15 days from sowing (DFS).

2- Pyrazosoulfuron ethyl WP $10 \%$ (Sirius) was applied at rate of $80 \mathrm{gm} / \mathrm{fed}$ after 10 days from sowing.

3- Fenoxaprop ethyl EW $7.5 \%$ (Whip super) at rate of $350 \mathrm{~cm} / \mathrm{fed}$ at $4^{\text {th }}$ leaf stage of rice.

4- Penoxsulam OD 25\% (Rainbow) at rate of 400 $\mathrm{cm} /$ fed after $15 \mathrm{DFS}$.

5- Bentazon AS 48\% (Basagran) at rate of 1.5 L/fed after 15 DFS + Fenoxaprop ethyl EW $7.5 \%$ (Whip super) at rate of $350 \mathrm{~cm} / \mathrm{fed}$ at $4^{\text {th }}$ leaf stage of rice.

6- Bentazon AS 48\% (Basagran) at rate of 1.5 L/fed after 15 DFS+ Penoxsulam OD 25\% (Rainbow) at rate of $400 \mathrm{~cm} / \mathrm{fed}$ after $15 \mathrm{DFS}$.

7- Pyrazosoulfuron ethyl WP $10 \%$ (Sirius) at rate of $80 \mathrm{gm} / \mathrm{fed}$ after 10 DFS + Fenoxaprop ethyl EW $7.5 \%$ (Whip super) at rate of $350 \mathrm{~cm} / \mathrm{fed}$ at the $4^{\text {th }}$ leaf stage of rice.

8- Pyrazosoulfuron ethyl WP 10\% (Sirius) at rate of $80 \mathrm{gm} / \mathrm{fed}$ after 10 DFS + Penoxsulam OD $25 \%$ (Rainbow) was applied at rate of 400 $\mathrm{cm} /$ fed after 15 DFS.

9- Hand weeding twice after 30 and 45 days from sowing.

10- Unweeded check (control).

Rice c.v. Giza 178 was sown on May $30^{\text {th }}$ in both seasons at $70 \mathrm{~kg} / \mathrm{fed}$. The sand coating involves mixing the herbicides and broadcast by hand. All the recommended cultural practices of growing rice were applied. During the growing seasons, one weed sample was taken randomly by using one square meter from each plot after 60 DFS. Number, fresh and dry weight of total weed species were estimated. Rice was harvested at September $20^{\text {th }}$ in both seasons. Plant height, No. of productive tillers, fresh and dry weight of whole plants, panicle length, number of panicles $/ \mathrm{m}^{2}$ and weight of 1000 grain were recorded.

The grain and straw yields were calculated in $\mathrm{t} / \mathrm{fed}$. NPK percentages of rice grain were determined by Micro Kjeidahl technique as description by Chapman and Pratt (1978). All the obtained data were statistically analyzed according to Snedecor and Cochran (1981) using L.S.D. to compare between the means.

\section{RESULTS AND DISCUSSION}

\section{I- Weeds}

The major weed species presented in the experimental area were common Echinochloa crus galli (L.) Beauv (Barnyardgrass), Echinochilon columum (L.) Link (Jungle Rice), Cyperus difformis (L.) Smallflower umbrellaplant, Cyperus longus (L.) Nutsedge.

\section{A- Effect of bio horm}

Results in Table (2) reveal that bio horm treatment significantly affect on total fresh and dry weight of weeds after 60 days from sowing. Application of bio horm increased fresh and dry weight of weeds in both seasons as compared with untreated plots. No significant effect of bio horm treatment was found on the total number of weeds $/ \mathrm{m}^{2}$.

\section{B- Effect of weed management}

The results in Table (2) clear that weed control treatments had a significant effect on number, fresh and dry weight of total weeds $/ \mathrm{m}^{2}$ after 60 
Table 2. Number, fresh and dry weight of total weeds after 60 days from sowing as affected by bio horm and weed management during 2007 and 2008 seasons

\begin{tabular}{|c|c|c|c|c|c|c|}
\hline \multirow{2}{*}{ Treatments } & \multicolumn{2}{|c|}{$\begin{array}{c}\text { Total number } \\
\text { of } \\
\text { weeds } / \mathrm{m}^{2}\end{array}$} & \multicolumn{2}{|c|}{$\begin{array}{l}\text { Total fresh } \\
\text { weight } \\
\text { of weeds } / \mathrm{m}^{2}\end{array}$} & \multicolumn{2}{|c|}{$\begin{array}{c}\text { Total dry } \\
\text { weight } \\
\text { of weeds } / \mathrm{m}^{2}\end{array}$} \\
\hline & 2007 & 2008 & 2007 & 2008 & 2007 & 2008 \\
\hline Bio horm & 7.9 & 7.9 & 1457 & 1431.9 & 302.3 & 297.2 \\
\hline Control & 8.1 & 7.8 & 1292 & 1279.4 & 263.7 & 257.4 \\
\hline F - Test & NS & NS & ** & ** & ** & ** \\
\hline L.S.D. at $5 \%$ & $\ldots$ & $\ldots$ & 95.3 & 61.62 & 15.29 & 10.78 \\
\hline 1-Bentazon & 9.0 & 9.3 & 1884 & 1822.5 & 365.4 & 354.3 \\
\hline 2-Pyrazosoulfuron & 6.0 & 5.8 & 788 & 758.3 & 149.9 & 144.3 \\
\hline 3-Fenoxaprop ethyl & 7.6 & 8.0 & 1535 & 1542.5 & 321.7 & 324.0 \\
\hline 4-Penoxsulam & 7.0 & 7.1 & 1434 & 1436.6 & 297.6 & 298.0 \\
\hline 5-Bentazon+Fenoxaprop ethyl & 8.8 & 8.5 & 1479 & 1471.6 & 302.5 & 304.3 \\
\hline 6- Bentazon + Penoxsulam & 8.3 & 6.5 & 788 & 759.3 & 145.1 & 139.8 \\
\hline 7- Pyrazosoulfuron+ Fenoxaprop ethyl & 6.7 & 6.2 & 690 & 818.0 & 152.6 & 150.7 \\
\hline 8-Pyrazosoulfuron+ Penoxsulam & 6.3 & 6.0 & 834 & 798.8 & 157.9 & 151.3 \\
\hline 9-Hand weeding twice & 7.1 & 7.0 & 949 & 907.5 & 177.1 & 170.4 \\
\hline 10-Unweeded check & 15.3 & 15.8 & 3360 & 3241.6 & 760.0 & 736.0 \\
\hline F - Test & ** & ** & ** & ** & ** & ** \\
\hline L.S.D. at $5 \%$ & 1.23 & 1.07 & 214 & 137.79 & 34.19 & 24.11 \\
\hline
\end{tabular}

DFS, in first and second seasons. In both seasons, the highest decrease in total number of weeds was obtained by Pyrazosoulfuron followed by Pyrazosoulfuron + Penoxsulam and Pyrazosoulfuron + Fenoxaprop treatments. Pyrazosoulfuron + Fenoxaprop treatment gave the highest decrease in total fresh weight of weeds followed by Bentazon + Penoxsulam, Pyrazosoulfuron and Pyrazosoulfuron + Penoxsulam treatments, respectively in 2007 season. While, in the second season, Pyrazosoulfuron treatment gave the lowest value of total fresh weight of weeds. Bentazon + Penoxsulam was more effective than other treatments in reducing the dry weight of total weeds in both seasons. Pyrazosoulfuron came in the second rank followed by Pyrazosoulfuron + Fenoxaprop, Pyrazosoulfuron + Penoxsulam treatments in the two seasons. However, there were no significant differences among the superior treatments. All herbicides used in this study are selective postemergence herbicides with intensive control of broad-leaved weeds or grassy weeds. Bentazon and Pyrazosoulfuron are selective post-emergence herbicides for controlling broad-leaved weeds and Cyperus difformis as well as Cyperus longus. Fenoxaprop is selective post-emergence herbicides for controlling Echinochloa crus - galli, Echinochilon columum while, Penoxsulam for controlling Cyperus difformis, Echinochloa crus - galli and Echinochilon columum. In general, application of herbicides mixtures in sequence was more effective than single herbicide. Similar results were obtained by Moorthy (2002) and Zhang et al (2005). These results may be due to the inhibition effect of weed control treatments on growth of weeds.

\section{II- Rice plants}

\section{1- Growth}

Plant height, number of productive tillers as well as fresh and dry weight of rice plant has been estimated under different treatments of bio horm and weed management as shown in Table (3). 
Table 3. Plant height, number of productive tillers, fresh and dry weight of rice plant after 60 days from sowing as affected by bio horm and weed management during 2007 and 2008 seasons

\begin{tabular}{|l|c|c|c|c|c|c|c|c|}
\hline \multirow{2}{*}{ Characters } & \multicolumn{2}{|c|}{$\begin{array}{c}\text { Plant height } \\
\text { (cm) }\end{array}$} & \multicolumn{2}{c|}{$\begin{array}{c}\text { No. of } \\
\text { productive } \\
\text { tillers/plant }\end{array}$} & \multicolumn{2}{c|}{$\begin{array}{c}\text { Fresh weight } \\
\text { (g/plant) }\end{array}$} & \multicolumn{2}{c|}{$\begin{array}{c}\text { Dry weight } \\
\text { (g/plant) }\end{array}$} \\
\cline { 2 - 9 } & $\mathbf{2 0 0 7}$ & $\mathbf{2 0 0 8}$ & $\mathbf{2 0 0 7}$ & $\mathbf{2 0 0 8}$ & $\mathbf{2 0 0 7}$ & $\mathbf{2 0 0 8}$ & $\mathbf{2 0 0 7}$ & $\mathbf{2 0 0 8}$ \\
\hline Bio horm & 59.1 & 58.8 & 18.3 & 18.3 & 74.6 & 72.6 & 27.3 & 27.6 \\
Control & 55.9 & 56.1 & 16.2 & 16.4 & 65.7 & 66.3 & 23.5 & 23.7 \\
F - Test & $* *$ & $* *$ & $* *$ & $* *$ & $* *$ & $* *$ & $* *$ & $* *$ \\
L.S.D. at 5\% & 1.38 & 1.06 & 1.00 & 0.56 & 2.86 & 3.48 & 1.02 & 0.74 \\
1-Bentazon & 53.1 & 52.5 & 15.3 & 15.3 & 58.8 & 59.0 & 21.5 & 21.6 \\
2-Pyrazosoulfuron & 60.8 & 59.5 & 19.1 & 19.0 & 78.8 & 72.9 & 28.7 & 28.4 \\
3-Fenoxaprop ethyl & 54.3 & 53.3 & 16.3 & 16.1 & 66.2 & 66.1 & 24.1 & 24.1 \\
4-Penoxsulam & 54.8 & 56.1 & 18.1 & 18.3 & 70.6 & 69.5 & 25.7 & 25.3 \\
5-Bentazon + Fenoxaprop ethyl & 58.1 & 59.1 & 18.1 & 17.5 & 68.1 & 68.8 & 24.8 & 25.1 \\
6-Bentazon + Penoxsulam & 62.0 & 60.6 & 19.1 & 19.6 & 81.0 & 81.1 & 29.4 & 29.4 \\
7-Pyrazosoulfuron+Fenoxaprop & 60.8 & 60.8 & 18.1 & 18.0 & 75.5 & 76.9 & 27.5 & 28.0 \\
$\quad$ ethyl & & & & & & & & 29.7 \\
8-Pyrazosoulfuron+Penoxsulam & 61.5 & 62.8 & 19.0 & 19.1 & 77.5 & 81.7 & 28.2 & 29.7 \\
9-Hand weeding (twice) & 58.3 & 58.0 & 16.5 & 17.3 & 70.7 & 67.6 & 25.8 & 26.4 \\
10-Unweeded check & 51.0 & 51.6 & 13.0 & 13.1 & 49.7 & 50.8 & 18.2 & 18.6 \\
\hline F - Test & $* *$ & $* *$ & $* *$ & $* *$ & $* *$ & $* *$ & $* *$ & $* *$ \\
\hline L.S.D. at 5\% & 3.08 & 2.39 & 2.25 & 1.27 & 6.41 & 7.78 & 2.28 & 1.67 \\
\hline
\end{tabular}

\section{A- Effect of bio horm}

Bio horm had a significant effect on plant height, number of productive tillers as well as fresh and dry weight of rice plant. In this connection, bio horm increased significantly the previous characters as compared to without bio horm treatment in both seasons Table (3). The increase in growth characters by bio horm treatment could be due to stimulating dry mass production through enhancement of cell division and chlorophyll accumulation which leads to higher photosynthetic activity, accumulation of dry matter, turn reflected on the increasing in translocation accumulation of certain microelements in plant organs, this in turn on their growth characters (Salama and Awadalla, 1987). Smirnoff (1996) reported that the increase in the growth and development of plants in response to antioxidant treatment might be due to the enlargement of cell division and/or the influence on DNA replication. El-Hamzawi (1996) found that shoot dry weight of wheat plants was significantly increased by foliar spray of citric or ascorbic acid. The increase of shoot dry weight of wheat plants may be due to the effect of the organic acids on many metabolic and physiological processes, mineral uptake and phyto-hormone balance. Also, Miernyk and Trelease (1981) stated that citric acid as an organic acid presented in tricarboxylic acid cycle and synthesized either from acetyl CoA, glycine and ketoglutaric, or malic acid convertioncitric acid. It can be mentioned that plant height reached its maximum value when plants sprayed with bio horm. Confirming results in this respect were cited by Amin (2003), Mourad (2006) and Al-Kahal et al (2008).

\section{B- Effect of weed management}

According to results in Table (3) plant height, number of productive tillers as well as fresh and dry weight of rice plant were significantly affected 
by weed management treatments in both seasons. Bentazon + Penoxsulam was superior treatment for increasing plant height, fresh and dry weight of plant in the first season. Also, the same treatment produced maximum values of number of productive tillers in 2007 and 2008 seasons. Moreover, Pyrazosoulfuron + Penoxsulam treatment was statistically leveled for improving each of plant height as well as fresh and dry weight of plant in second season. On the other hand, the lowest values of the aforementioned characters were recorded from the unweeded treatment in the first and second seasons. The enhancement of rice growth in the weeded plots might be attributed to the efficiency in weed elimination and consequently decreased weed competitive ability against rice plants. This made more efficient use of the environmental growth factors by rice plants reflecting on improving their growth. Successful integrate chemical weed control in rice was recorded by EI Desoki (2002), Moorthy (2002) and Zhang et al (2005).

\section{2- Yield and its components}

Yield and its components criteria of rice plants as affected by bio horm and weed management treatments are presented in Table (4).

\section{A- Effect of bio horm}

Results in Table (4) demonstrated that bio horm treatment markedly increased number of panicles $/ \mathrm{m}^{2}$, weight of 1000 grain, grain yield and straw yield in both seasons. Moreover, bio horm treatment significantly increased panicle length in the second season only. Plant growth substances counteracting the deleterious effects of salinity on plant growth and yield by increasing succulence in plant due to the increase in cell number and elongation, tend to dilute the internal ionic concentration (Ismail, 2003). In addition, it may induce the cambium differentiation to yield xylem and phloem tissue which improved the absorption and conducting water to the growing organs and improved the translocation of photo-assimilate thus increased plant growth and yield. Ozdemir et al (2004) reported that the role of growth substances (kinetin) or antioxidant (salcilic and citric acid) on overcoming the depressing effect of salinity stress on growth and biochemical constituents may be due to one or more of the following: (a) Increase root dry weight and decreasing root resistance to water flow and $\mathrm{Cl}^{+}$uptake. (b) Nullifying the changes on mineral composition, photosynthetic pigments and endogenous hormonal level. (c) Increasing water absorption capacity of the roots. (d) Increasing $\mathrm{K}^{+}$uptake and sugars accumulation within the plant tissues as well as oligosaccharides contents (e) increasing water status within the plant tissues by sustaining the determined metabolite level including selective $\mathrm{K}^{+}$over $\mathrm{Na}^{+}$increasing organic acid contents and ion uptake.(f)increasing stimulators/inhibitors ratio in the plant tissues. (g) Increasing carbohydrates, proline and organic acids which can be used as an indicator in the osmoregulation of tissues under salinity stress. The positive effect of growth substances or antioxidant practices on rice yield and its components have been conformed by (Abd El- Wahed et al 2003; Abd El-Fattah, 2008 and El-Mwafy, 2008).

\section{Effect of weed management}

All weed management statistically increased panicle length, number of panicles $/ \mathrm{m}^{2}$, weight of 1000 grain, grain and straw yield in both seasons Table (4). The highest increase in panicle length, number of panicles $/ \mathrm{m}^{2}$, weight of 1000 grain, grain and straw yield was obtained by Bentazon $+\mathrm{Pe}$ noxsulam treatment. Grain yield was markedly affected by weed management treatments in both seasons. The highest increase in grain yield was obtained by Bentazon + Penoxsulam, Pyrazosoulfuron, Pyrazosoulfuron + Penoxsulam, Pyrazosoulfuron + Fenoxaprop, twice hand weeding and Penoxsulam. The increases amounted to 108.2, $100.0,87.3,81.8,59.1$ and $47.3 \%$ in the first season and, 101.8, 96.0, 81.7, 78. .86, 56.3 and $42.0 \%$ in the second season over the unweeded treatment, respectively.

The increase in yield attributed by different weed control treatments may be due to good control of rice weeds and minimizing weed competition which gave good chance of rice growth and improved good characters. The promoting effect of weed control treatments on plant height, panicle length, No. of panicles $/ \mathrm{m}^{2}$, No. of productive tillers and weight of 1000 grain weight criteria may be reflected on increasing the yield and its components of rice plants. Also, this in turns increased plant height (until harvesting) and produced more assimilates synthesized, translocated and accumulated in various plant organs. Thus, positively on reflected biological, straw and grain yields.The positive effect of weeded practices on rice yield and its components have been conformed with Moorthy (2002); Govindra et al (2003); Cavanna et al (2004); Mondal et al (2005) and Zhang et al (2005). 
Table 4. Rice yield and its components as affected by bio horm and weed management during 2007 and 2008 seasons

\begin{tabular}{|c|c|c|c|c|c|c|c|c|c|c|}
\hline \multirow[b]{2}{*}{ Treatments } & \multicolumn{2}{|c|}{$\begin{array}{c}\text { Panicle } \\
\text { length } \\
\text { (cm) }\end{array}$} & \multicolumn{2}{|c|}{$\begin{array}{c}\text { No. of } \\
\text { Panicles } \\
/ \mathrm{m}^{2}\end{array}$} & \multicolumn{2}{|c|}{$\begin{array}{c}1000 \text { - grain } \\
\text { weight } \\
\text { (g) }\end{array}$} & \multicolumn{2}{|c|}{$\begin{array}{c}\text { Grain } \\
\text { yield } \\
\text { (ton) / fed. }\end{array}$} & \multicolumn{2}{|c|}{$\begin{array}{c}\text { Straw } \\
\text { yield } \\
\text { (ton) / fed. }\end{array}$} \\
\hline & 2007 & 2008 & 2007 & 2008 & 2007 & 2008 & 2007 & 2008 & 2007 & 2008 \\
\hline Bio horm & 21.2 & 21.2 & 310.5 & 312.0 & 24.0 & 24.4 & 3.62 & 3.59 & 4.78 & 4.85 \\
\hline Control & 20.5 & 20.3 & 288.8 & 288.8 & 21.3 & 21.4 & 3.38 & 3.37 & 4.53 & 4.48 \\
\hline F - Test & NS & ** & ** & ** & ** & ** & ** & ** & ** & ** \\
\hline L.S.D. at $5 \%$ & $\ldots$ & 0.66 & 4.84 & 3.77 & 0.52 & 0.34 & 0.07 & 0.04 & 0.07 & 0.02 \\
\hline 1-Bentazon & 19.3 & 19.5 & 282.0 & 288.0 & 21.7 & 22.3 & 2.80 & 2.92 & 3.95 & 4.07 \\
\hline 2-Pyrazosoulfuron & 21.3 & 21.8 & 320.0 & 320.0 & 23.9 & 24.1 & 4.40 & 4.39 & 5.55 & 5.54 \\
\hline 3-fenoxaprop ethyl & 20.6 & 20.1 & 289.3 & 283.3 & 22.3 & 22.1 & 2.97 & 2.92 & 4.12 & 4.07 \\
\hline 4-Penoxsulam & 21.1 & 21.0 & 293.3 & 292.6 & 22.3 & 22.4 & 3.24 & 3.18 & 4.39 & 4.33 \\
\hline 5- Bentazon + Fenoxaprop ethyl & 21.0 & 20.8 & 289.3 & 290.0 & 22.3 & 22.6 & 3.15 & 3.04 & 4.35 & 4.22 \\
\hline 6- Bentazon + Penoxsulam & 22.3 & 21.3 & 322.6 & 326.6 & 24.3 & 24.2 & 4.58 & 4.52 & 5.73 & 5.72 \\
\hline $\begin{array}{l}\text { 7-Pyrazosoulfuron+Fenoxaprop } \\
\text { ethyl }\end{array}$ & 21.3 & 22.3 & 312.6 & 316.6 & 22.9 & 23.2 & 4.00 & 4.00 & 5.15 & 5.15 \\
\hline 8- Pyrazosoulfuron + Penoxsulam & 21.5 & 21.3 & 316.0 & 314.6 & 23.1 & 23.4 & 4.12 & 4.07 & 5.27 & 5.50 \\
\hline 9-Hand weeding (twice) & 21.1 & 20.8 & 298.0 & 298.6 & 22.7 & 23.1 & 3.50 & 3.50 & 4.65 & 4.65 \\
\hline 10-un weeded check & 19.0 & 18.3 & 273.3 & 271.5 & 21.0 & 21.1 & 2.20 & 2.24 & 3.35 & 3.39 \\
\hline F-Test & * & ** & ** & ** & ** & ** & ** & ** & ** & ** \\
\hline L.S.D. at $5 \%$ & 1.83 & 1.48 & 10.83 & 8.43 & 1.17 & 0.76 & 0.16 & 0.10 & 0.17 & 0.45 \\
\hline
\end{tabular}

\section{3- Chemical composition of rice grains}

\section{A- Effect of bio horm}

The percentage of nitrogen, phosphorus and potassium was appreciably influenced by bio horm treatment in both seasons Table (5). The increases in nitrogen, phosphorus and potassium content in rice grains with bio horm may be due to the stimulation and enhancement of cell division and chlorophyll accumulation which led to higher photosynthetic activity of rice plants and this in turn enhancement of rice growth and increased nitrogen, phosphorus and potassium accumulation in rice grains (Abd El-Fattah 2008). Growth substances used increased phosphorus content caused an increase in photosynthetic rates resulting in increasing the dry matter accumulation (Foyer and Harbinson, 1994). Also, Growth substances used increased potassium content in shoot under normal and saline conditions. Potassium plays a vital role in a wide range of biochemical and biophysical processes in plants. It is a highly mobile charge carrier, neutralizes the effects of anions, and plays an important role in enzymes activation and membrane transport (Hasegawa et al 2000). The same conclusion was mentioned by Amin (2003), Mourad (2006), Abd El-Fattah
(2008), Al-Kahal, et al (2008) and El-Mwafy (2008).

\section{B- Effect of weed management}

Weed management had a significant effect on nitrogen, phosphorus and potassium percentage of rice grains Table (5). Bentazon + Penoxsulam treatment increased significantly the content of $\mathrm{N}$, $\mathrm{P}$, and $\mathrm{K} \%$ in grains as compared to the unweeded check. The increments of $\mathrm{N}, \mathrm{P}$ and $\mathrm{K} \%$ exceeded the unweeded treatment by $81.3,75.0$ and $80.0 \%$ in the first season, 76.3, 75.0 and 75.0 in the second season, respectively. These results may be due to the less competition for environment factors particularly nutrients, water and light through limiting weeds infestation with herbicidal treatments due to increasing the uptake of different nutrients. Similar results were obtained by El-Kholy et al (1999) and El-Desoki (2003).

\section{III- The interaction between bio horm and weed management}

The results in Table (6) indicated that the interaction between bio horm and weed control treatments on total fresh and dry weight of weeds $/ \mathrm{m}^{2}$, number of productive tillers after 60 days from sowing and 1000-grain weight . 
Table 5. Averages of $\mathrm{N}, \mathrm{P}$, and $\mathrm{K}$ elements percentage in rice grain as affected by bio horm and weed management during 2007 and 2008 seasons

\begin{tabular}{|l|c|c|c|c|c|c|}
\hline \multirow{2}{*}{ Treatments } & \multicolumn{2}{|c|}{ Nitrogen \% } & \multicolumn{2}{c|}{ Phosphorus \% } & \multicolumn{2}{c|}{ Potassium \% } \\
\cline { 2 - 7 } Bio horm & $\mathbf{2 0 0 7}$ & $\mathbf{2 0 0 8}$ & $\mathbf{2 0 0 7}$ & $\mathbf{2 0 0 8}$ & $\mathbf{2 0 0 7}$ & 2008 \\
Control & 1.08 & 1.08 & 0.11 & 0.11 & 0.29 & 0.28 \\
F- Test & 1.01 & 1.01 & 0.10 & 0.10 & 0.27 & 0.27 \\
L.S.D. at 5\% & $* *$ & $* *$ & $* *$ & $* *$ & $* *$ & $* *$ \\
1-Bentazon & 0.022 & 0.013 & 0.002 & 0.001 & 0.006 & 0.003 \\
2-Pyrazosoulfuron & 0.83 & 0.87 & 0.08 & 0.09 & 0.22 & 0.23 \\
3-fenoxaprop ethyl & 1.30 & 1.30 & 0.14 & 0.13 & 0.35 & 0.35 \\
4-Penoxsulam & 0.88 & 0.87 & 0.09 & 0.09 & 0.23 & 0.23 \\
5- Bentazon + Fenoxaprop ethyl & 0.96 & 0.94 & 0.10 & 0.10 & 0.25 & 0.25 \\
6- Bentazon + Penoxsulam & 0.93 & 0.90 & 0.10 & 0.09 & 0.25 & 0.24 \\
7-Pyrazosoulfuron+Fenoxaprop ethyl & 1.36 & 1.34 & 0.14 & 0.14 & 0.36 & 0.35 \\
8- Pyrazosoulfuron + Penoxsulam & 1.19 & 1.19 & 0.12 & 0.12 & 0.31 & 0.31 \\
9-Hand weeding (twice) & 1.04 & 1.21 & 0.13 & 0.12 & 0.32 & 0.32 \\
10-un weeded check & 0.75 & 0.76 & 0.08 & 0.08 & 0.20 & 0.20 \\
\hline F- Test & $* *$ & $* *$ & $* *$ & $* *$ & $* *$ & $* *$ \\
\hline L.S.D. at 5\% & 0.049 & 0.031 & 0.005 & 0.003 & 0.013 & 0.008 \\
\hline
\end{tabular}

Table 6. Averages of fresh and dry weight of total weeds, number of productive tillers and 1000 grain weight as affected by the interaction between bio horm and weed management during 2007 and 2008 seasons

\begin{tabular}{|c|c|c|c|c|c|c|c|c|c|c|}
\hline \multirow[b]{3}{*}{ Treatments } & \multicolumn{2}{|c|}{$\begin{array}{l}\text { Total fresh } \\
\text { weight } \\
\text { of weeds } / \mathrm{m}^{2}\end{array}$} & \multicolumn{4}{|c|}{$\begin{array}{c}\text { Total dry } \\
\text { weight } \\
\text { of weeds } / \mathrm{m}^{2}\end{array}$} & \multicolumn{2}{|c|}{$\begin{array}{c}\text { No. of } \\
\text { productive } \\
\text { tillers }\end{array}$} & \multicolumn{2}{|c|}{$\begin{array}{c}1000 \text { - grain } \\
\text { weight } \\
\text { (g) }\end{array}$} \\
\hline & $\begin{array}{c}\text { Bio- } \\
\text { horm }\end{array}$ & $\begin{array}{c}\text { Con- } \\
\text { trol }\end{array}$ & $\begin{array}{c}\text { Bio- } \\
\text { horm }\end{array}$ & $\begin{array}{c}\text { Con- } \\
\text { trol }\end{array}$ & $\begin{array}{l}\text { Bio- } \\
\text { horm }\end{array}$ & $\begin{array}{c}\text { Con- } \\
\text { trol }\end{array}$ & $\begin{array}{l}\text { Bio- } \\
\text { horm }\end{array}$ & $\begin{array}{c}\text { Con- } \\
\text { trol }\end{array}$ & $\begin{array}{l}\text { Bio- } \\
\text { horm }\end{array}$ & $\begin{array}{c}\text { Con- } \\
\text { trol }\end{array}$ \\
\hline & \multicolumn{2}{|c|}{2008} & \multicolumn{2}{|c|}{2007} & \multicolumn{2}{|c|}{2008} & \multicolumn{2}{|c|}{2008} & \multicolumn{2}{|c|}{2008} \\
\hline 1-Bentazon & 1920.3 & 1724.6 & 381 & 349.5 & 375.0 & 333.7 & 17.0 & 13.6 & 23.6 & 21.1 \\
\hline 2-Pyrazosoulfuron & 796.0 & 720.6 & 168 & 131.6 & 163.8 & 124.9 & 20.3 & 17.6 & 26.1 & 22.1 \\
\hline 3-Fenoxaprop ethyl & 1611.3 & 1473.6 & 340 & 303.4 & 342.7 & 305.3 & 17.0 & 15.3 & 22.9 & 21.2 \\
\hline 4-Penoxsulam & 1465.6 & 1407.6 & 320 & 275.4 & 315.9 & 280.1 & 19.0 & 17.6 & 23.8 & 21.0 \\
\hline 5- Bentazon + Fenoxaprop ethyl & 1483.0 & 1460.3 & 320.6 & 284.5 & 310.1 & 298.5 & 20.0 & 15.0 & 24.0 & 21.3 \\
\hline 6- Bentazon + Penoxsulam & 809.0 & 709.6 & 153.3 & 136.9 & 150.9 & 128.6 & 19.6 & 19.6 & 26.4 & 22.1 \\
\hline 7-Pyrazosoulfuron+Feoxaprop ethyl & 826.3 & 809.6 & 153.8 & 151.4 & 154.4 & 147.0 & 18.6 & 17.3 & 24.9 & 21.6 \\
\hline 8- Pyrazosoulfuron+ Penoxsulam & 811.3 & 786.3 & 166.2 & 149.1 & 160.8 & 141.8 & 20.0 & 18.3 & 25.0 & 21.8 \\
\hline 9-Hand weeding (twice) & 980.0 & 835.0 & 192.3 & 162.0 & 186.0 & 154.9 & 17.3 & 17.0 & 24.5 & 21.7 \\
\hline 10-Un weeded & 3616.3 & 2867.0 & 827.6 & 692.5 & 812.6 & 659.5 & 14.0 & 12.3 & 21.9 & 20.4 \\
\hline $\mathrm{F}-$ Test & \multicolumn{2}{|c|}{ 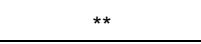 } & & \multicolumn{2}{|c|}{ ** } & \multicolumn{2}{|c|}{ * } & \\
\hline L.S.D. & \multicolumn{2}{|c|}{194.40} & \multicolumn{2}{|c|}{48.25} & \multicolumn{2}{|c|}{34.02} & \multicolumn{2}{|c|}{1.79} & \multicolumn{2}{|c|}{1.06} \\
\hline
\end{tabular}


Results also cleared that there was a significant interaction effect between bio horm and weed management treatments on total fresh weight of weeds $/ \mathrm{m}^{2}$ in 2008 season and dry weight of weeds $/ \mathrm{m}^{2}$ in 2007 and 2008 seasons Table (6). Bentazon + Penoxsulam without bio horm produced the lowest values of total fresh weight of weeds in 2008 season. Pyrazosoulfuron without bio horm produced the lowest values of total dry weight of weeds $/ \mathrm{m}^{2}$ in both seasons. Bentazon + Penoxsulam without biohormone came in the second rank followed by Pyrazosoulfuron + Penoxsulam when bio horm unused. Vice - versa, unweeded treatment with bio horm recorded the highest values of fresh weight of total weeds $/ \mathrm{m}^{2}$ in the first season. These results are in good harmony with those of Abd El-Wahed et al (2003).

According to results in Table (6) indicated that the interaction between bio horm and weed control treatments on number of productive tillers after 60 days from sowing was significant. The highest number of productive tillers was obtained from foliar sprayed bio horm with Pyrazosoulfuron followed by Bentazon+ Fenoxaprop and Pyrazosoulfuron + Penoxsulam treatments. In contrast, the lowest value of number of productive tillers was recorded from the unweeded treatment with spraying of water (control) in average of the second season. These results are in good harmony with those of Abd El-Wahed et al (2003).

Results in Table (6) indicated that there was a significant interaction between bio horm and weed control treatments on 1000- grain weight in the second season. The maximum values of 1000 grain weight was obtained from bio horm foliar spray with Bentazon + Penoxsulam followed by Pyrazosoulfuron and Pyrsoulfuron + Penoxsulam treatments. On the other hand, the lowest value of 1000- grain weight was recorded from the unweeded treatment with spraying of water (control) in the second season. These results are in good harmony with those of Abd El-Wahed et al (2003).

\section{REFERENCES}

Abd El-Fattah, G.A. (2008). Physiological and Morphological Studies on Some Rice Cultivars and their Relation to Salt Tolerance pp.11-28. Ph. D. Thesis, Fac. Agric., Mansoura Univ., Egypt. Abd El-Wahed, M.S.A.; E.R. El-Desoki and R.A. El-Mergawi (2003). Influence of the herbicide (thiobencarb) and sitosterol on rice plant (Oryza sativa L.). J. Agric. Sci., Mansoura Univ., 28(3): 16551671.
Al-Kahal, A.A.; S.M. Ahmed and M.M. Fahmy (2008). Response of barley growth, yield and microbial population in the rhizosphere to soil application of yeast and foliar spray of citric and ascorbic acid. J. Agric. Sci., Mansoura Univ., 33(11): 7783-7791.

Amin, A.A. (2003). Physiological effect of gamma irradiation and kinetin on growth yield and chemical constituents of wheat. Egypt, J. Appl. Sci., 18(6): 34-49.

Arrioni, O. and M.C. DeTullio (2002). Ascorbic acid: much more than just an antioxidant. Biochimica et Biophysica Acta.1569: 1-9.

Cavanna, S.; L. Bacci; D. Larelleand and A. Carone (2004). Penoxsulam: New post-emergence rice herbicide. Giornate-Fitopatologische-2004,Montesilvano-Pescara,-4-6-Maggio-2004-Atti,volume-primo: 301-307.

Chapman, H.D. and P.F. Pratt (1978). Methods for Analysis for Soil, Plant and Water pp. 50-67. Dept. of Agric. Sci., California Univ., USA.

Conklin, P.L. and C. Barth (2004). Ascorbic acid, a familiar small molecule intertwined in the response of plants to ozone, pathogens and the onset of senescence. Plant Cell and Environment., 27: 959-971.

El-Desoki, E.R. (2002). Effect of some weed control treatments and levels of nitrogen on performance of direct seeded rice and weeds. Egypt, J. Appl. Sci., 17(8): 124-137.

El-Desoki, E.R. (2003). Effect of some weed control treatments on transplanting rice and nutrients uptake by rice and weeds. J. Agric. Sci., Mansoura Univ., 28(1): 23-35.

El-Hamzawi, D.S.S. (1996). Biochemical Studies on Some Organic Acids on Some Plants pp. 15-23. M.Sc., Thesis, Fac. Agric. Sci., Cairo Univ. El-Kholy, M.H.; M.H. Hegazy and F.K. Abd ElFattah (999). Response of rice yield to $\mathrm{N}$-fertilizion, BGA inoculation and herbicide application. J. Agric. Sci., Mansoura Univ., 24(9): 5165-5173.

El-Mwafy, M.R.A. (2008). Effect of Some Antioxidant on Seed Quality and Yield of Wheat pp. 30-34. Ph.D. Thesis, Fac. Agric., Mansoura, Univ., Egypt.

Foyer, C.H. and J. Harbinson (1994). Oxygen metabolismand the regulation of photosynthetic electron transport.In: Foyer, C. and P. Mullincaux (eds.): Causes of Photooxidative Stresses and Amelioration of Defense Systems in Plants pp. 1-42, CRC Press, Boca Raton, FL.

Govindra, S.; V.P. Singh; M. Singh and S.P. Singh (2003). Effect of fenoxaprop-p-ethyl on 
transplanted rice and associated weed. Indian J. of Weed Sci., 35(1/2): 119-120.

Hasegawa, P.M.; R.A. Bressan; J.K. Zhu and H.J. Bohnert (2000). Plant cellular and molecular responses to high salinity. Annu. Rev., Plant Physiol. Plant Mol. Biol., 51: 463-499.

Ismail, A.M. (2003). Physiological studies on the influence of cytokinin or GA3 in the alleviation of salt stress in sorghum plants. Acta-AgronomicaHungarica. 51(4): 371-380.

Larelle, D.; R. Mann; S. Cavanna; R. Bernes; A. Duriatti and C. Mavrotas (2003). Penoxsulam,a new broad spectrum rice herbicide for weed control in European Union paddies. The - BCPC International - Congress :-Crop-Science -and Technology.-Volumes-1-and-2-Proceedings -of -An-International -Congress-held-at-the-SECC, Glasgow, -Scotland, -UK, -10-12-November2003, pp. 75-80.

Li, L.; J. Van Staden and A.K. Jager (1998). Effects of plant growth regulators on the antioxidant system in two maize cultivars subjected to water stress. Plant Growth Reg., 25: 81-87.

Miernyk, J.A. and R.N. Trelease (1981). Role of malate synthesis in citric acid synthesis by maturing cotton embryos. Plant Physiol., 68: 875-881.

Mondal, D.C.; A. Hossain and B. Duary (2005). Effect of pyrazosulfuron-ethyl on weeds and yield of transplanted rice under lateritic belt of West Bengal. Indian J. of Weed Sci., 37(3/4): 263-264.
Moorthy, B.T.S. (2002). Evaluation pyrazosulfuron -ethyl alone and in combination with molinate for controlling weeds in rainfed direct -seeded lowland yield. Indian J. of Weed Sci., 34(3/4): 285-286.

Mourad, A.E.A.A. (2006). Response of grain sorghum to foliar spray with ascorbic and citric acids under different rates of nitrogen fertilizer in sandy soils. J. Agric. Sci., Mansoura Univ., 31(11): 6825-6837.

Ozdemir, O.; B. Melike, D. Tijen and T. Ismail (2004). Effects of 24-epibrassinolide on seed germination, seedling growth, lipid peroxidation, praline cotent and antioxidative system of rice (Oryza sativa L.) under salinity stress. Plant Growth Regulation. 42: 203-211.

Saini, J.P. (2003). Efficacy of pyrazosulfuron-ethyl against mixed weed flora in transplanted rice. Pesticide Res. J., 15(2): 157-159.

Salama, F.M. and A.A. Awadalla (1987). The effects of different kinetin application methods on some chlorophyll parameters of two crop plants grown under salinity stress. Phyton. 21: 81-193.

Smirnoff, N. (1996). The function and metabolism of ascorbic acid in plant. Annual Bot., 78: 661669.

Snedecor, G.W. and W.G. Cochran (1981). Statistical Methods. $7^{\text {th }}$ Ed., pp. 325-330. lowa State Univ., Press, Ames., USA.

Zhang, W.; E.P. Webster; D.C. Blouin and C.T. Leon (2005). Fenoxaprop interactions for barnyardgrass (Echinochloa crus-galli) control in rice. Weed Technology. 19 (2): 293-297. 